\title{
IZBOR RACIONALNOG METODA ANALIZE ARMIRANOBETONSKIH POLIEDARSKIH LJUSKI U FUNKCIJI NJIHOVOG RASPONA
}

\author{
Danica Goleš $\check{1}^{1}$ \\ Dragan Milašinović ${ }^{2}$ \\ Žarko Živanov ${ }^{3}$
}

UDK: $624.074: 517.9$

DOI: 10.14415/zbornikGFS22.002

Rezime: Dve armiranobetonske poliedarske ljuske, raspona 20 i $30 \mathrm{~m}$, dimenzionisane su prema presečnim uticajima određenim primenom linearnog metoda konačnih traka. Za odabrane karakteristične preseke ljuski konstruisani su interakcioni dijagrami sa krivama loma dobijenim primenom radnih dijagrama betona $i$ armature prema Evrokodu 2 i reološko-dinamičkoj analogiji. Sukcesivnim povećanjem opterećenja kroz geometrijski nelinearnu analizu konstrukcija primenom harmonijski spojenog metoda konačnih traka određeno je granično opterećenje ljuski, pri kojem dolazi do loma karakterističnih preseka. Poređenjem koeficijenata sigurnosti sračunatih na osnovu rezultata linearne i geometrijski nelinearne analize izveden je zaključak o racionalnom metodu analize zavisno od dužine ljuske.

Ključne reči: Armirani beton, poliedarska ljuska, metod konačnih traka, linearna analiza, geometrijski nelinearna analiza, dužina ljuske.

\section{UVOD}

Analiza konstrukcija se danas gotovo isključivo zasniva na primeni numeričkih metoda, pre svega metoda konačnih elemenata (MKE). Za posebnu klasu konstrukcija i elemenata, čije su geometrijske i fizičke karakteristike konstantne duž jednog pravca, razvijen je metod konačnih traka (MKT), koji u odnosu na MKE ima znatno manji broj konačnih traka kao i ulazno-izlaznih podataka [1].

Klasičan MKT polazi od pretpostavke o malim pomeranjima, te se primenjuje za linearnu analizu konstrukcija. Međutim, kod konstrukcija poput dugih poliedarskih ljuski i sl., geometrijski nelinearno ponašanje se ne može zanemariti. MKT u kojem se uzimaju u obzir velika pomeranja razvio je Milašinović [2]. Ovaj metod, za razliku od klasičnog MKT, obuhvata međudelovanje članova reda (harmonika) pri formiranju matrice

\footnotetext{
${ }^{1}$ dr Danica Golcš, dipl. inž. građ., Građcvinski fakultet Subotica, Kozaračka 2a, tcl: 024/554-300, e-mail: dgoles@gf.uns.ac.rs

${ }^{2}$ Prof. dr Dragan D. Milašinović, dipl inž grad., Gradevinski fakultet Subotica, Kozaračka 2a, tel: 024/554-300, e-mail: ddmil@gf.uns.ac.rs

${ }^{3}$ Doc. dr Žarko Živanov, dipl. inž. elektr. i računar., Fakultet tehničkih nauka, Trg D. Obradovića 6 , tel: 021/485-2000, e-mail: zzarko@uns.ac.rs
} 
krutosti, zbog čega je nazvan harmonijski spojen metod konačnih traka (HSMKT). Kako je postupak određivanja elemenata matrice krutosti traka u HSMKT veoma složen i zahtevan u pogledu utroška vremena računara, koriste se različite strategije za optimizaciju, poput MPI i Open MPI paralelizacije [3] i [4].

U svojim ranijim radovima [5]-[7] autori su, samo na osnovu primene linearnog MKT, zaključili da se prizmatične poliedarske ljuske odabranog poprečnog preseka i raspona do $L=15 \mathrm{~m}$ (kojima odgovara odnos dužina/širina ljuske $\mathrm{L} / \mathrm{B}=1.29$, tj. odnos raspona pojedinih ploča poliedra $\left.1_{\mathrm{y}} / 1_{\mathrm{x}}=4.78\right)$ mogu smatrati "kratkim" i analizirati primenom linearnog MKT, dok "duge" ljuske, raspona preko $L=25 \mathrm{~m}$ ( $\mathrm{L} / \mathrm{B}=2.15$, odnosno $\left.1_{\mathrm{y}} / 1_{\mathrm{x}}=7.97\right)$, treba analizirati uzimajući u obzir njihovo geometrijski nelinearno ponašanje, primenom HSMKT. Ovo su potvrdila i kasnija istraživanja [8]-[10], koja su takođe pokazala da se kod ljuski "srednjeg" raspona $\left(\mathrm{L}-20 \mathrm{~m}, \mathrm{~L} / \mathrm{B}-1.72,1_{\mathrm{y}} / \mathrm{l}_{\mathrm{x}}-6.37\right)$ presečne sile dobijene primenom linearne $\mathrm{i}$ geometrijski nelinearne analize međusobno razlikuju za manje od $10 \%$, pri čemu proračun prema linearnoj MKT uvek daje rezultate koji su na strani sigurnosti. Imajući u vidu da je klasičan MKT jednostavniji, brži i manje zahtevan u pogledu kapaciteta računara i utroška vremena, samim tim i jevtiniji za primenu nego HSMKT, nametnuo se zaključak da je linearan MKT optimalan izbor i za analizu poliedarskih ljuski "srednjeg" raspona, i pored toga što bi se dimenzionisanjem ljuske prema rezultatima geometrijski nelinearne analize postigla određena ušteda u materijalu. Cilj ovog rada je da se ispita opravdanost i pouzdanost primene linearne MKT na analizu armiranobetonskih prizmatičnih poliedarskih ljuski srednjeg raspona, te da se ocene efekli uvođenja pretpostavke o velikim pomeranjinla kod poliedarskih ljuski srednjeg raspona u odnosu na efekte uvodenja iste pretpostavke $u$ analizi "dugih" ljuski. $U$ tu svrhu izvršena je analiza prizmatičnih poliedarskih ljuski raspona $L=20 \mathrm{~m}$ i $L=30 \mathrm{~m}$ primenom linearnog MKT (LIN) i geometrijski nelinearnog HSMKT zasnovanog na predviđanjima Green-Lagrange-a (LAG), odnosno von Karman-a (VK), te uporedo prikazani dijagrami presečnih sila. Dimenzionisanje karakterističnih preseka obe ljuske je sprovedeno u skladu sa PBAB'87, prema presečnim uticajima određenim primenom linearnog MKT. Za odabrane karakteristične preseke obe ljuske konstruisani su dijagrami interakcije $\left(N_{u}-M_{u}\right)$ upotrebom radnih dijagrama betona $\mathrm{i}$ armature prema Evrokodu 2 (EC 2) i prema reološko-dinamičkoj analogiji (RDA). Na osnovu njih su određene granične nosivosti preseka, granična opterećenja i globalni koeficijenti sigurnosti za pretpostavke malih i velikih pomeranja, te odabrana racionalna metoda analize $\mathbf{u}$ funkciji raspona ljuske.

\section{OPIS PREDMETA I METODA ANALIZE}

U ovom radu su analizirane dve armiranobetonske prizmatične poliedarske ljuske raspona $20 \mathrm{i} 30 \mathrm{~m}$, istog poprečnog preseka, izvedene od betona MB $45(\mathrm{C} 35 / 45)$ i armature RA 400/500-2. Proračunski modul elastičnosti je $E=34 \mathrm{GPa}$, a Poisson-ov koeficijent $v=0$. Krajevi obe ljuske $(y=0$ i $y=L)$ su oslonjeni na armiranobetonske dijafragme krute u svojoj ravni, pa su u analizi usvojene trake koje su na krajevima slobodno oslonjene, a svaka ima po osam stepeni slobode kretanja. Numerička analiza je sprovedena samo za polovinu konstrukcije, jer je iskorišćena simetrija geometrije, opterećenja i uslova oslanjanja. Na slici 1 je prikazan poprečni presek sa servisnim 
opterećenjem, mreža konačnih traka (ukupno 10), njihove oznake i oznake čvornih linija, kao i orjentacija globalnog koordinatnog sistema.

Za potrebe geometrijski nelinearne analize primenom HSMKT opterećenje je podeljeno u 37 inkremenata. Intenzitet opterećenja u prvom inkrementu odgovara veličini stalnog opterećenja, peti inkrement predstavlja servisno, a šesnaesti granično opterećenje sračunato prema PBAB'87 primenom parcijalnih koeficijenata sigurnosti. Maksimalno optcrećcnjc je usvojeno kao trostruka vrcdnost cksploatacionog, sa namcrom da sc dostigne granično stanje konstrukcije. Proračun presečnih uticaja je sproveden za pretpostavke linearnog (LIN) i geometrijski nelinearnog ponašanja konstrukcija prema predviđanjima Green-Lagrange-a (LAG) i von Karman-a (VK), korišćenjem 21 člana reda.

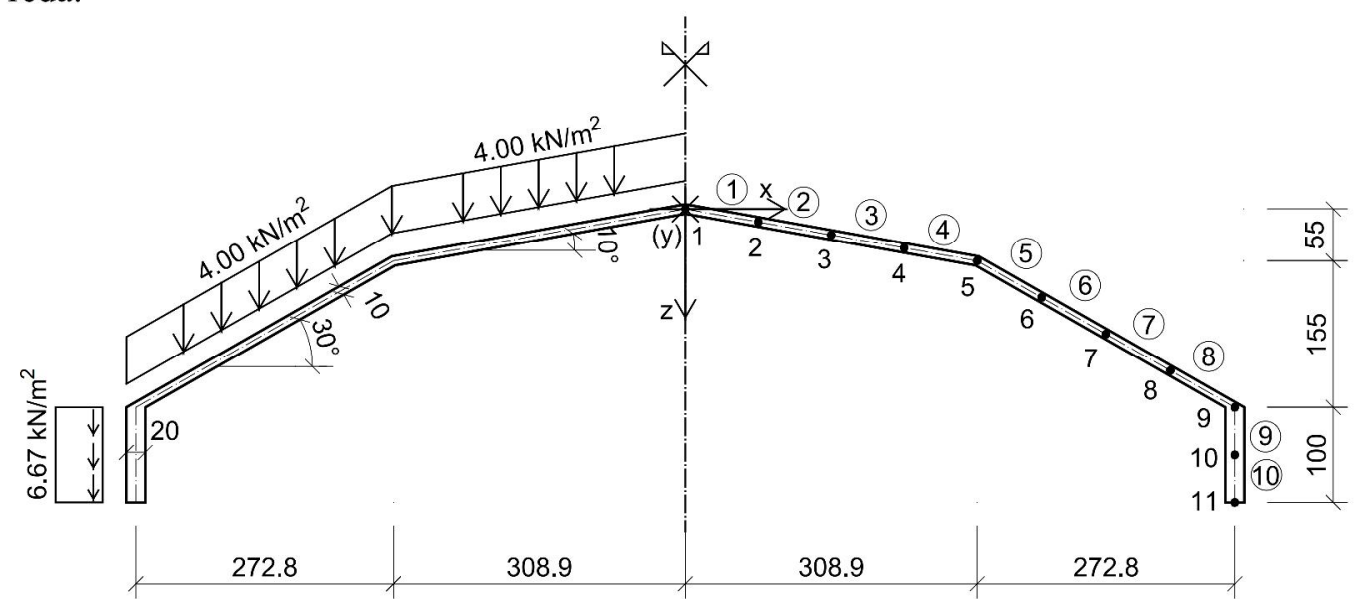

Slika 1. Poprečni presek, servisno opterećenje i mreža konačnih traka prizmatičnih poliedarskih ljuski

$\mathrm{Na}$ osnovu presečnih uticaja određenih primenom LIN metoda izvršeno je dimenzionisanje karakterističnih preseka obe ljuske u skladu sa PBAB'87. Odabrana su po dva karakteristična preseka u sredini raspona za obe ljuske, te su za njih konstruisani dijagrami interakcije $\left(N_{u}-M_{u}\right)$ korišćenjem radnih dijagrama betona i armature prema EC 2 (za nelinearnu analizu) i prema RDA sa maksimalnim dilatacijama betona ograničenim na $\varepsilon_{b}=3.5 \%$ (za konstrukciju radnih dijagrama betona $i$ armature primenom RDA videti [7] i [9]). Na osnovu ovih dijagrama interakcije određeni su i upoređeni granična nosivost, granična opterećenja i globalni koeficijenti sigurnosti karakterističnih preseka prema LIN, LAG i VK predviđanjima, te ocenjena veličina i priroda greške koja se čini uvođenjem pretpostavke o malim pomeranjima. $\mathrm{Na}$ osnovu ovih razmatranja izveden je zaključak o izboru racionalnog metoda analize armiranobetonskih poliedarskih ljuski različitih raspona.

\section{UPOREDNI PRIKAZ DIJAGRAMA PRESEČNIH UTICAJA}

Na slikama 2 i 3 uporedo su prikazani dijagrami presečnih uticaja u sredini raspona ljuski $L=20 \mathrm{~m}$ (levo) i $L=30 \mathrm{~m}$ (desno) prema LIN, LAG i VK predviđanjima, usled graničnog opterećenja sračunatog u skladu sa PBAB'87 (šesnaesti inkrement 
opterećenja). Slike 4-6 prikazuju dijagrame presečnih uticaja u presecima koji su od oslonaca (dijafragmi) udaljeni za desetinu raspona ( $y=2 \mathrm{~m}$ za ljusku $L=20 \mathrm{~m}$, odnosno $y=3 \mathrm{~m}$ za ljusku raspona $30 \mathrm{~m})$.
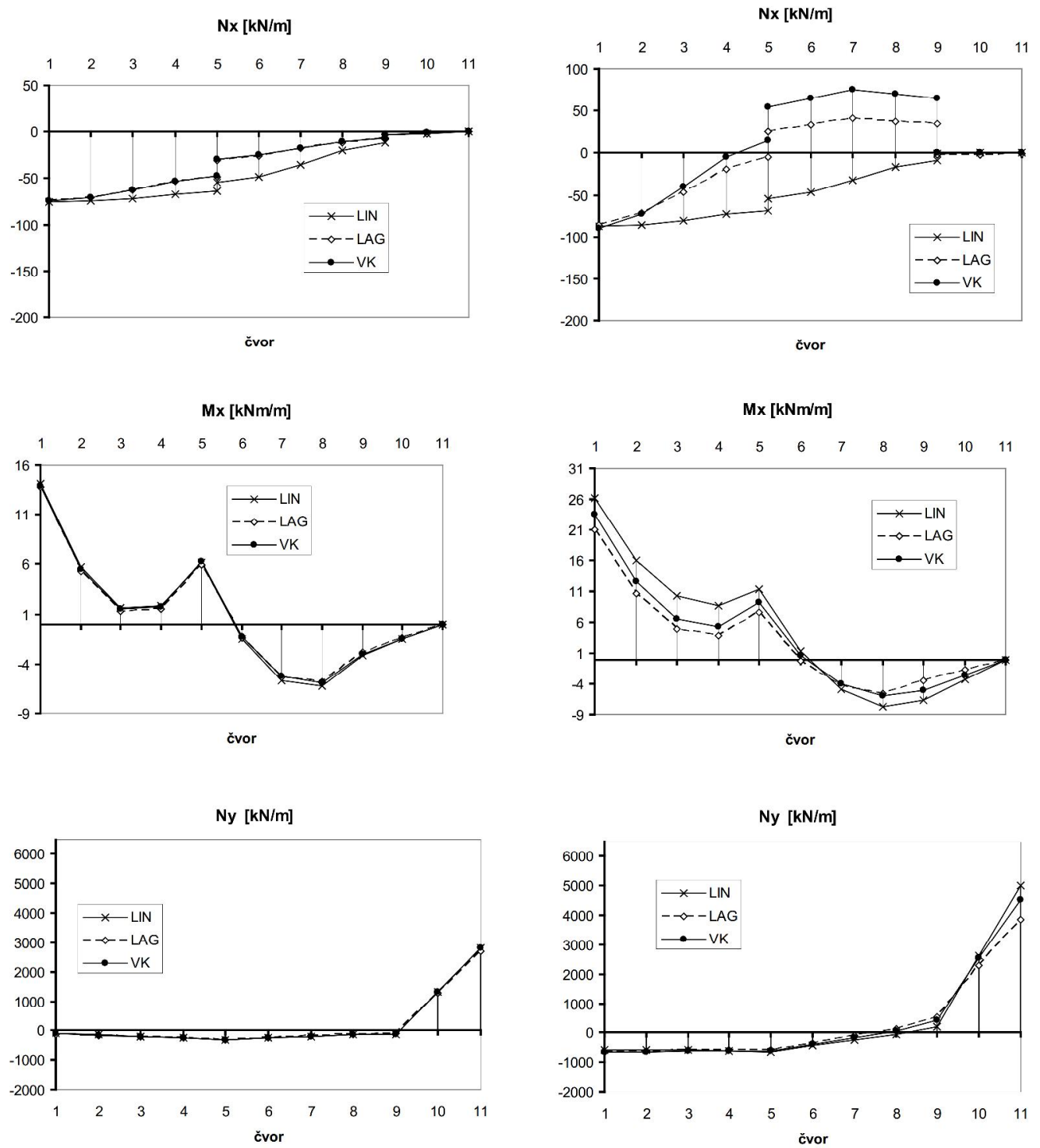

Slika 2. Uporedni prikaz dijagrama $N_{x}, M_{x} i N_{y}$ na sredini raspona usled graničnog opterećenja određenog prema PBAB'87 za $L=20 \mathrm{~m}$ (levo) $i L=30 \mathrm{~m}$ (desno)

Kod ljuske raspona $20 \mathrm{~m}$ uočava se gotovo potpuno poklapanje dijagrama presečnih uticaja prema LIN, LAG i VK predviđanjima, kako u sredini raspona tako i u presecima u blizini oslonaca. Ekstremne vrednosti presečnih uticaja u gotovo svim presecima dobijaju se prema LIN analizi. Izuzetak su membranska sila $N_{x}$ i moment torzije $M_{x y} \mathrm{u}$ ivičnoj gredi (čvorne linije 9 do 11) u preseku u blizini oslonca, gde se ekstremne vrednosti ovih uticaja dobijaju prema LAG odnosno VK predviđanjima. 

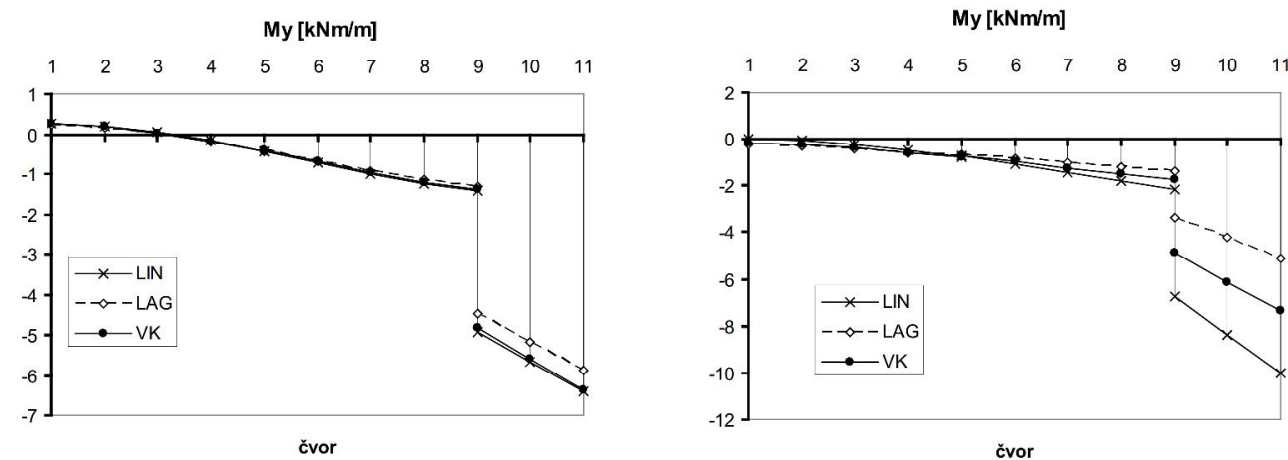

Slika 3. Uporedni prikaz dijagrama $M_{y}$ na sredini raspona usled graničnog opterećenja određenog prema PBAB'87 za L=20m (levo) i $L=30 \mathrm{~m}$ (desno)
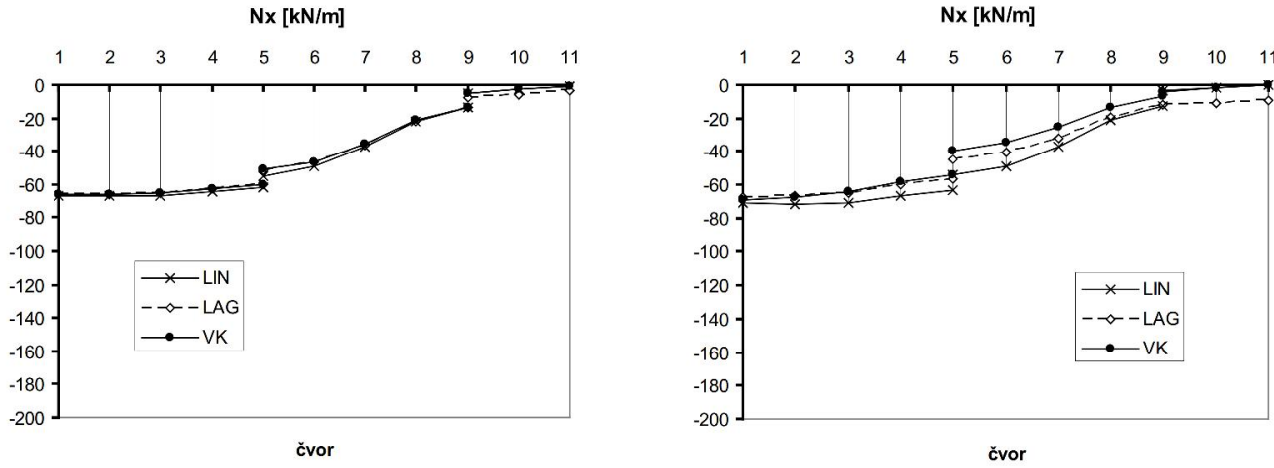

$\mathrm{Mx}[\mathrm{kNm} / \mathrm{m}]$
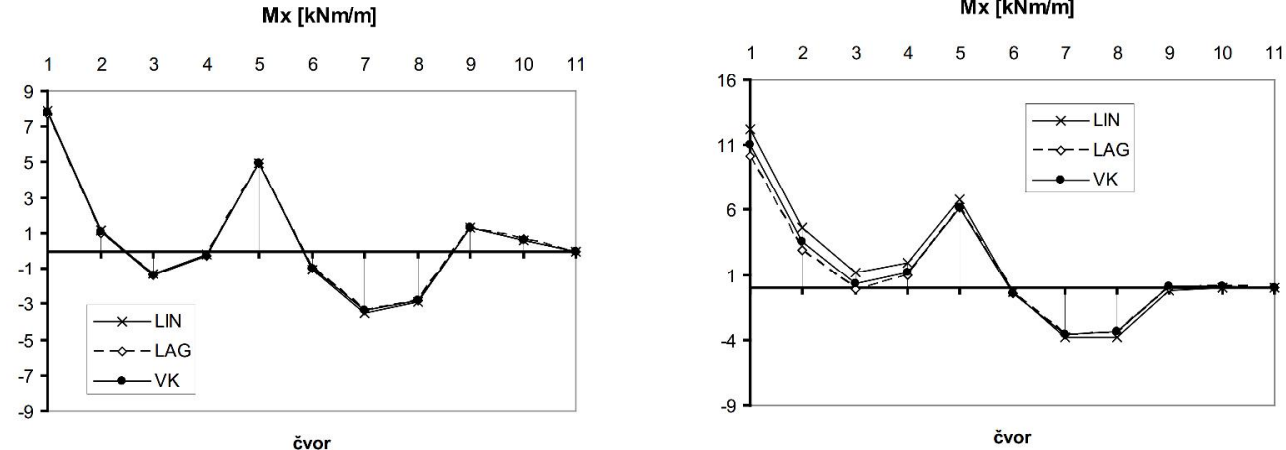

Slika 4. Uporedni prikaz dijagrama $N_{x} i M_{x}$ u preseku u blizini oslonca usled graničnog opterećenja određenog prema PBAB'87 za $L=20 \mathrm{~m}$ (levo) $i L=30 \mathrm{~m}$ (desno)

Značajne razlike u rezultatima linearne i geometrijski nelinearne analize uočavaju se kod duge ljuske. I ovde se može primetiti da se ekstremne vrednosti gotovo svih uticaja dobijaju uz pretpostavku o malim pomeranjima. Ovo bi moglo navesti na pogrešan zaključak da LIN analiza daje rezultate koji su na strani sigurnosti u odnosu na geometrijski nelinearnu analizu, te da se dimenzionisanjem poliedarskih ljuski prema klasičnom MKT dobijaju konstrukcije veće pouzdanosti, čak i u slučaju velikih raspona, 
iako uz nešto veći utrošak materijala. Konačan sud o ovome može se doneti tek na osnovu granične analize, koja će biti prikazana u sledećem poglavlju.

Ny $[\mathrm{kN} / \mathrm{m}]$

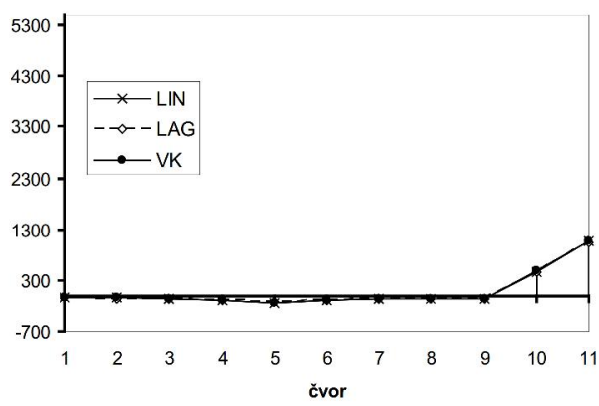

My $[\mathrm{kNm} / \mathrm{m}]$

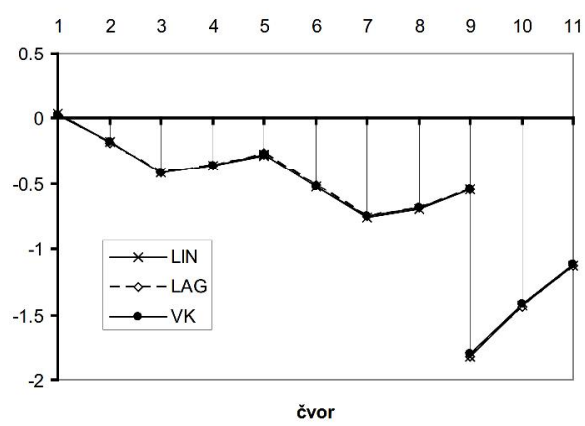

$\mathrm{Nxy}[\mathrm{kN} / \mathrm{m}]$

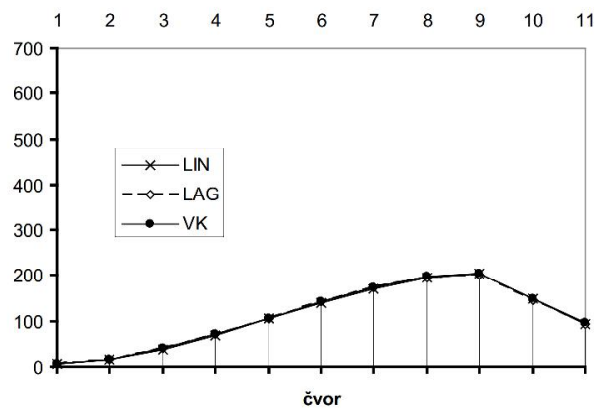

Ny $[\mathrm{kN} / \mathrm{m}]$

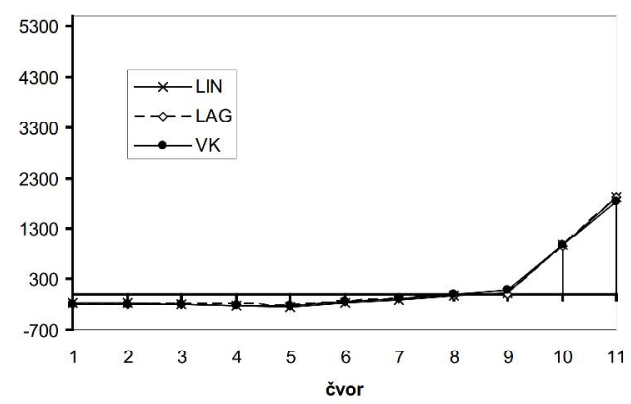

My $[\mathrm{kNm} / \mathrm{m}]$

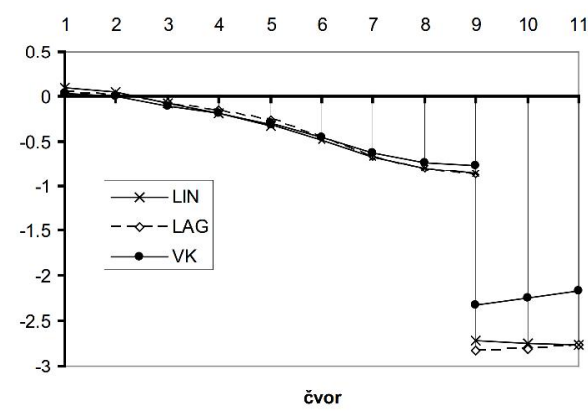

Nxy [kN/m]

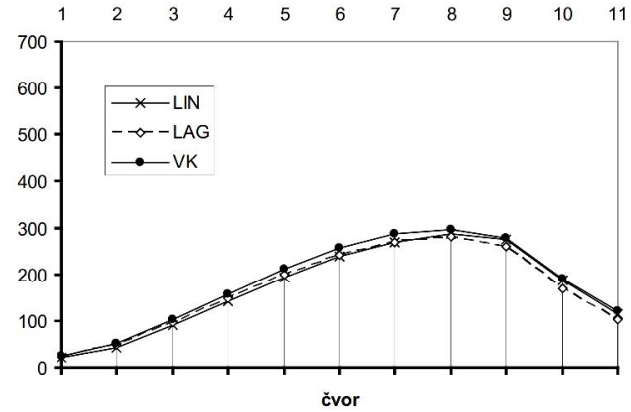

Slika 5. Uporedni prikaz dijagrama $N_{y}, M_{y} i N_{x y}$ u preseku u blizini oslonca usled graničnog opterećenja određtenog prema PBAB'87 za L=20m (levo) i $L=30 \mathrm{~m}$ (desno)

Ako se međusobno uporede dijagrami presečnih uticaja za ljuske raspona 20 i 30m, može se primetiti da imaju gotovo identičan oblik. Jedina značajna razlika vidi se kod dijagrama membranske sile $N_{x}$ u preseku na sredini raspona (slika 2). Nezavisno od izabranog metoda analize, ova sila u ljusci raspona $20 \mathrm{~m}$ ima u svim presecima pritiskujuće dejstvo. Kod duge ljuske, prema nelinearnim LAG i VK predviđanjima, sa udaljavanjem od temena ljuske (između čvornih linija 4 i 9) sila menja predznak i prelazi u zatezanje. Upravo će se ova pojava pokazati kao presudna za izbor metoda zasnovanih 
na pretpostavci o velikim pomeranjima, kao što je HSMKT, kao jedinih prihvatljivih metoda za analizu dugih poliedarskih ljuski.
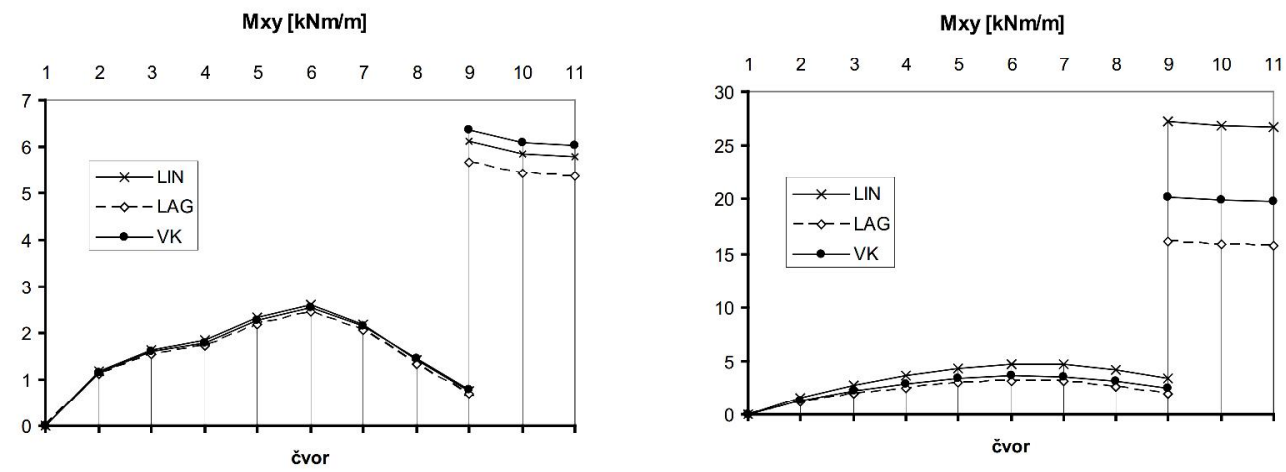

Slika 6. Uporedni prikaz dijagrama $M_{x y}$ u preseku u blizini oslonca usled graničnog opterećenja određenog prema PBAB'87 za L=20m (levo) $i L=30 \mathrm{~m}$ (desno)

\section{GRANIČNA ANALIZA KARAKTERISTIČNIH PRESEKA}

Granična analiza je sprovedena za po dva karakteristična preseka u sredini raspona ljuski: presek u temenu (čvorna linija 1), u kojem se javlja absolutno maksimalni moment savijanja $M_{x}$, i presek ivične grede (između čvornih linija 9 i 11), sa absolutno maksimalnim vrednostima podužne normalne sile $N_{y}$. Ovi poprečni preseci i odgovarajući dijagrami interakcije $\left(N_{u}-M_{u}\right)$ prikazani su na slikama 7-10.
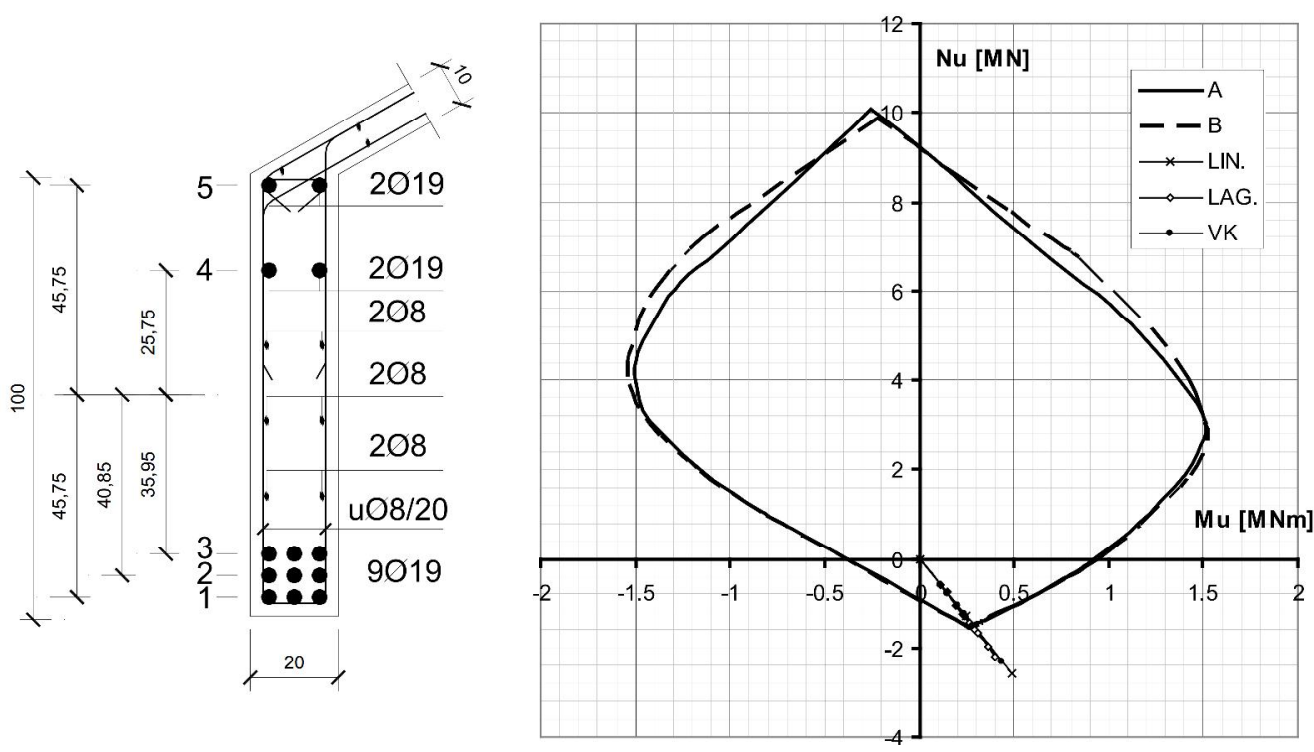

Slika 7. Poliedarska ljuska raspona $L=20 m$ : poprečni presek ivične grede u sredini raspona i odgovarajući $N_{u}-M_{u}$ dijagram 
$\mathrm{Na}$ interakcionim dijagramima krivom "A" je prikazana linija loma određena korišćenjem radnih dijagrama betona i čelika prema EC 2, dok su za konstrukciju linije loma "B" upotrebljeni radni dijagrami materijala određeni prema RDA [7], [9]. Parcijalni koeficijenti sigurnosti za materijal nisu primenjeni. Negativan predznak odgovara zatežućoj normalnoj sili. Pozitivan moment savijanja u ivičnoj gredi zateže donju ivicu poprečnog preseka.
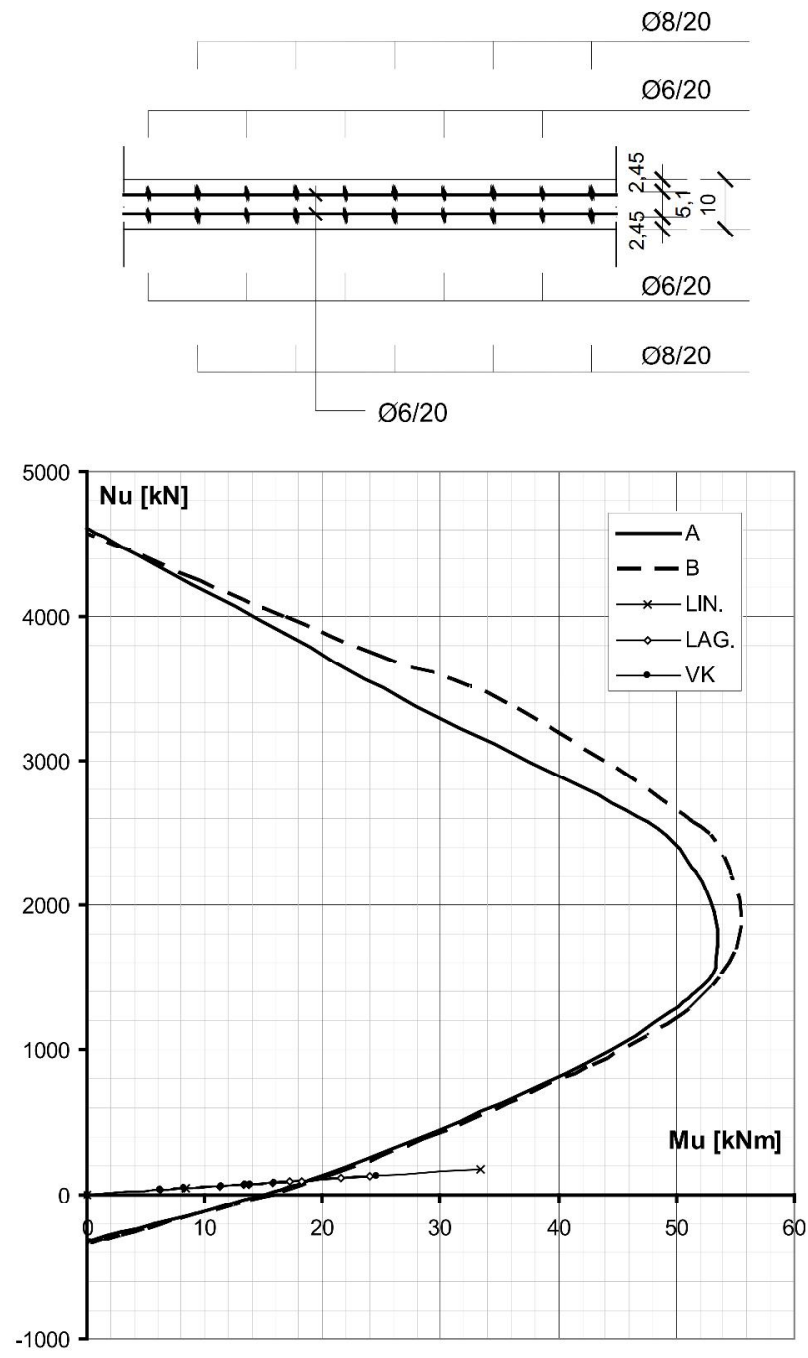

Slika 8. Poliedarska ljuska raspona L=20m: poprečni presek u čvornoj liniji 1 u sredini raspona i odgovarajući $N_{u}-M_{u}$ dijagram 

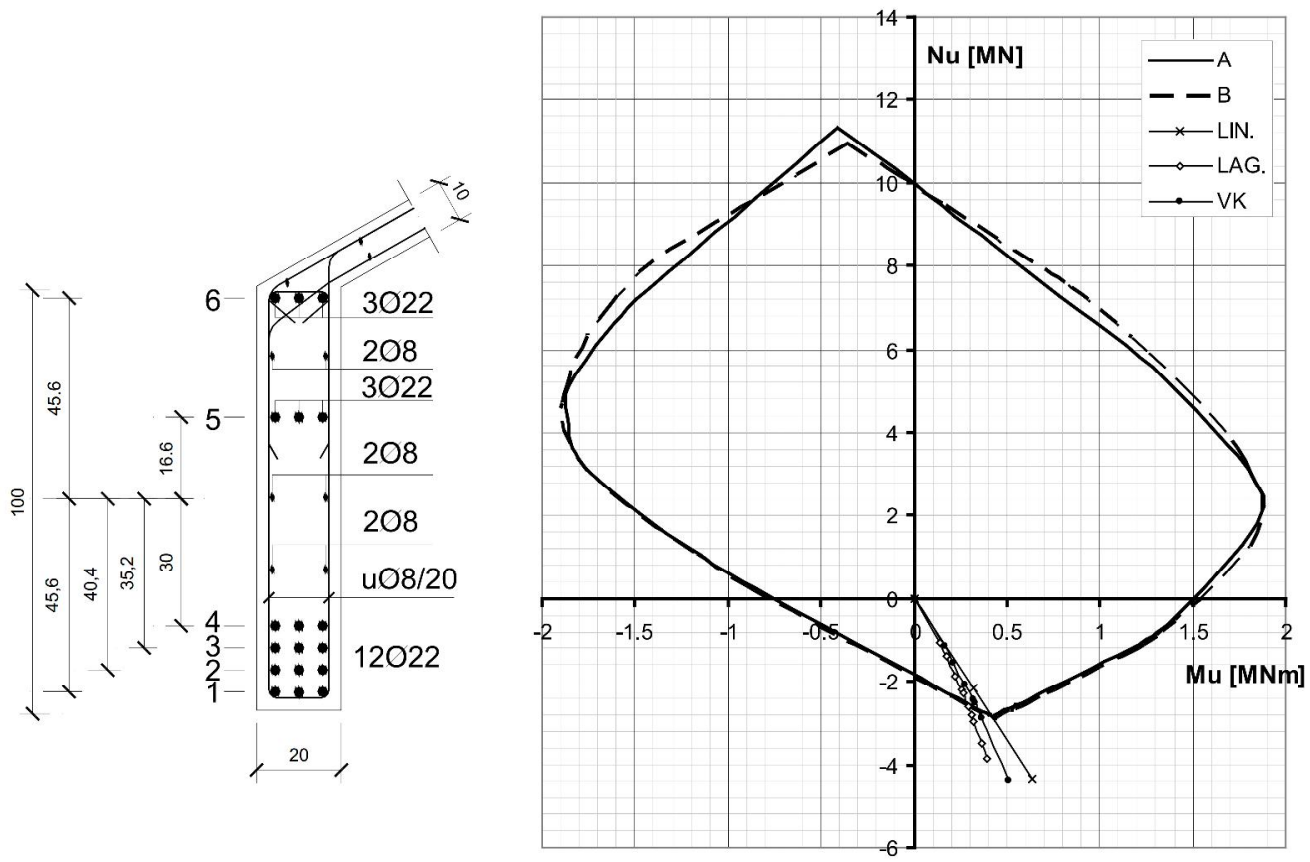

Slika 9. Poliedarska ljuska raspona $L=30 \mathrm{~m}$ : poprečni presek ivične grede u sredini raspona i odgovarajući $N_{u}-M_{u}$ dijagram

Na slici 11 prikazani su uvećani segmenti interakcionih dijagrama, na kojima se jasnije vidi promena funkcije $N-M$, sa povećavanjem opterećenja. Ova promena je linearna za LIN analizu, a izrazito nelinearna tek kod duge poliedarske ljuske za LAG predviđanja. Pri LIN analizi je dovoljno odrediti par $N-M$ za samo jedan inkrement opterećenja, budući da se sa povećanjem opterećenja menja samo intenzitet normalne sile $N$, a ne i njen ekscentricitet u odnosu na težište preseka. U preseku prave linije povučene iz koordinatnog početka kroz ovako sračunatu tačku $N-M$ i odgovarajuće linije loma, očitava se granična nosivost preseka $N_{u}$, kojoj odgovara globalni koeficijent sigurnosti $\gamma(N)=N_{u} / N$. U slučaju LIN predviđanja važi $\gamma(N)=\gamma(q)=q_{u} / q$.

Granična nosivost preseka primenom geometrijski nelinearne analize može se odrediti kao presečna tačka odgovarajuće linije loma preseka i krive koja spaja parove $N-M$ za razlicite nivoe opterecenja. U tu svrhu se opterećenje sukcesivno (po inkrementima) povećava, te se za svaki inkrement određuje novi par $N-M$. Linija koja predstavlja promenu funkcije $N-M$ sa porastom opterećenja je kriva linija, kao posledica ispisivanja uslova ravnoteže $u$ odnosu na deformisani nosač, zbog čega promena opterećenja izaziva ne samo promenu intenziteta normalne sile, nego i njenog ekscentriciteta u odnosu na težište preseka. Jednakost $\gamma(N)=\gamma(q)$ u slučaju geometrijski nelinearne analize više ne važi, nego se granično opterećenje dobija tako što se odredi inkrement opterećenja pri kome se dostiže granična nosivost preseka.

$\mathrm{Na}$ osnovu analize promene funkcije $N-M$ sa promenom opterećenja, koja se najbolje može videti na slici 11, uočava se da je geometrijski nelinearno ponašanje ljuske raspona $L=20 \mathrm{~m}$ veoma malo izraženo. Uticaj velikih pomeranja je značajniji kod duge 
poliedarske ljuske. Ovo se naročito primećuje u preseku ivične grede na sredini raspona ljuske $L=30 \mathrm{~m}$ za LAG predviđanje (slika 1 la desno). U svim analiziranim presecima VK predviđanje daje funkciju promene $N-M$ blisku linearnom ponašanju.
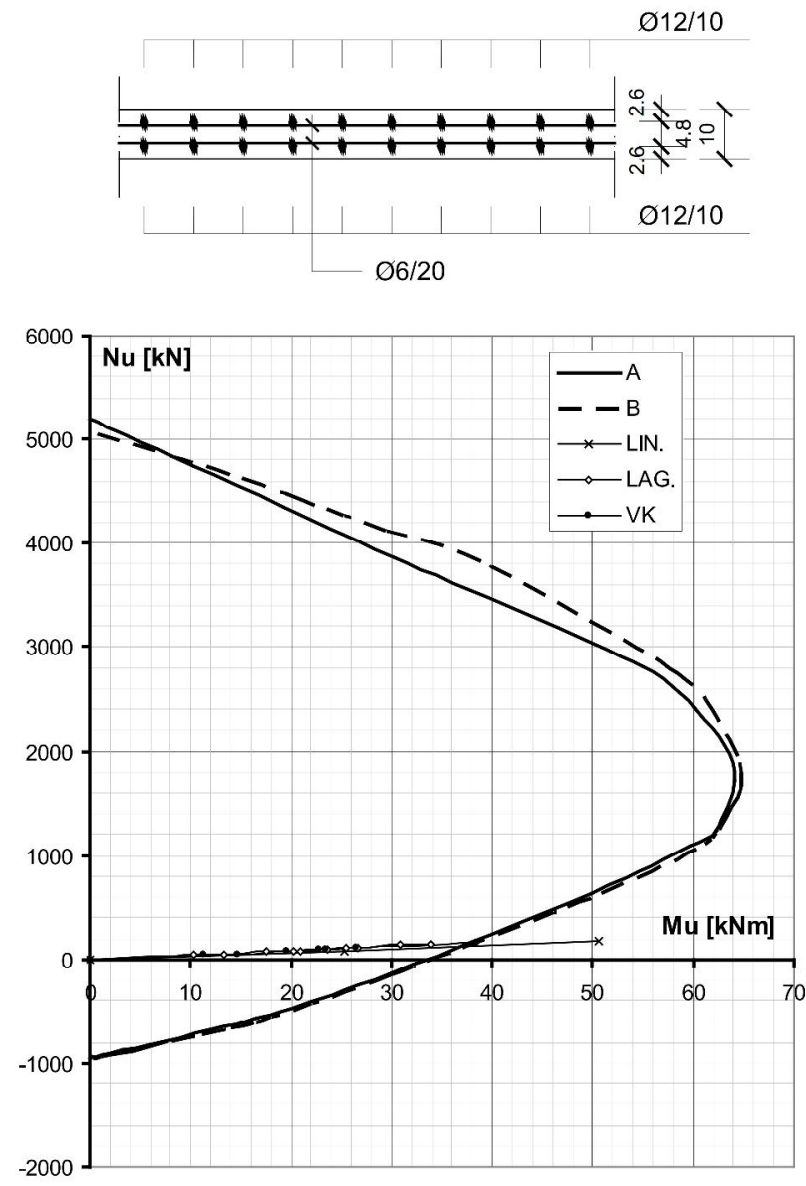

Slika 10. Poliedarska ljuska raspona L=30m: Poprečni presek u čvornoj liniji 1 u sredini raspona i odgovarajući $N_{u}-M_{u}$ dijagram

U tabelama 1 i 2 prikazane su granične nosivosti $N_{u}$ i globalni koeficijenti sigurnosti $\gamma(N)=N_{u} / N$ i $\gamma(q)=q_{u} / q$ odabranih poprečnih preseka obe poliedarske ljuske, prema LIN, LAG i VK predviđanjima. Ovde $N$ predstavlja membransku silu usled servisnog opterećenja q; granična nosivost $N_{u}$ se očitava sa dijagrama interakcije u preseku krive koja opisuje ponašanje funkcije $N-M$ sa porastom opterećenja i linije loma $N_{u}-M_{u}$, dok je $q_{u}$ granično opterećenje, odnosno opterećenje pri kojem se dostiže granična nosivost $N_{u}$ preseka.

U slučaju poliedarske ljuske srednjeg raspona, globalni koeficijenti sigurnosti sračunati na osnovu LIN predviđanja su uvek manji od vrednosti određenih na osnovu LAG i VK proračuna (tabele 1 i 2). To praktično znači da je dimenzionisanje armiranobetonskih poliedarskih ljuski srednjeg raspona na osnovu presečnih uticaja sračunatih primenom linearne analize na strani sigurnosti u odnosu na proračun koji uzima u obzir $\mathrm{i}$ 
geometrijski nelinearno ponašanje ovih konstrukcija. Pri tome je najveća razlika između koeficijenata sigurnosti sračunatih na bazi linearne i geometrijski nelinearne analize dobijena u ivičnij gredi za liniju loma "B", gde se $\gamma(q)$ po LIN i LAG predviđanju razlikuju za samo $5.9 \%$. Važno je napomenuti da se granično stanje nosivosti prema geometrijski nelinearnoj analizi dostiže pri većem nivou opterećenja nego u slučaju nelinearnog ponašanja, u svim analiziranim presecima ljuske srednjeg raspona, što se jasno možc videti na osnovu porcđenja odgovarajućih globalnih kocficijenata sigurnosti $\gamma(q)$ (tabele 1 i 2 ).
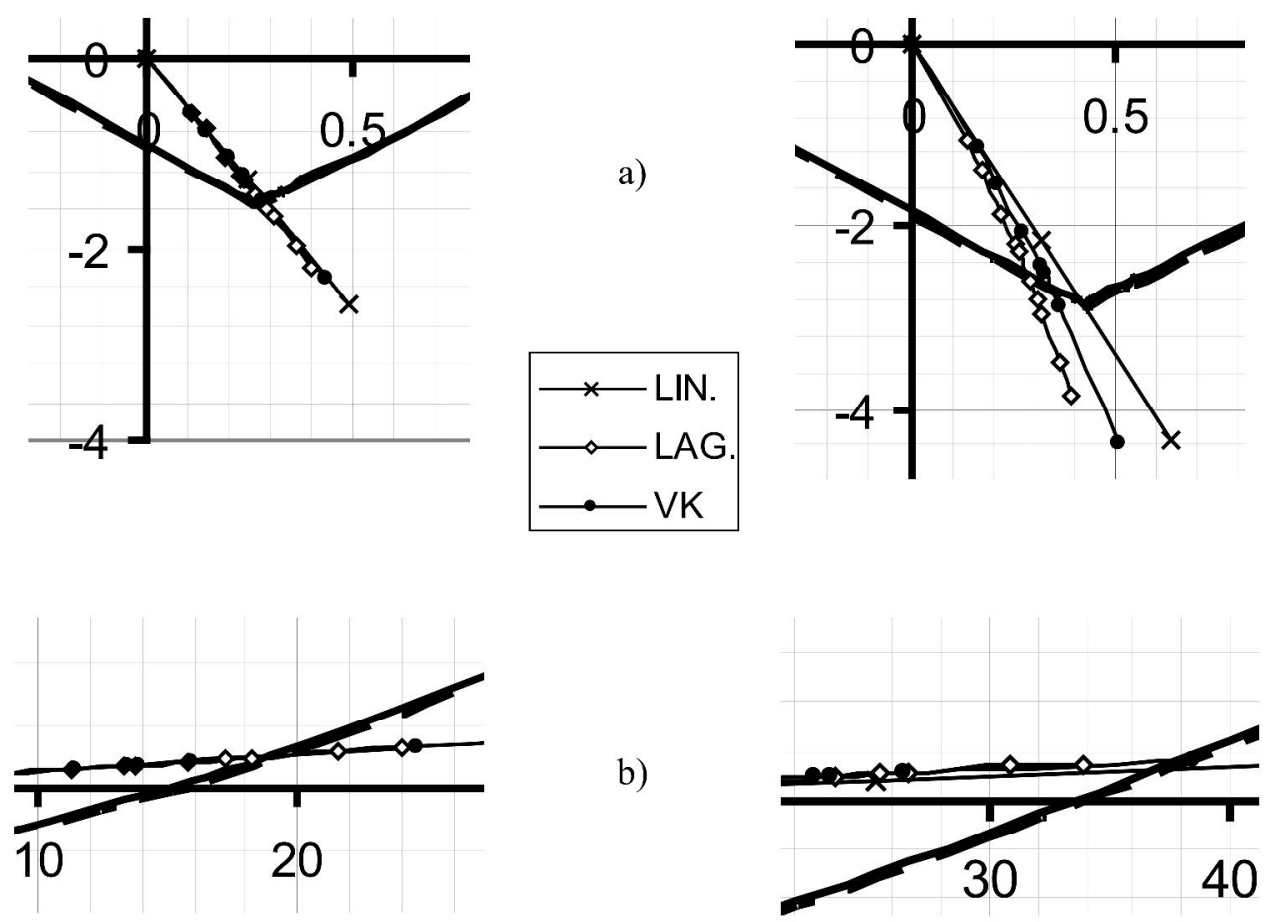

b)

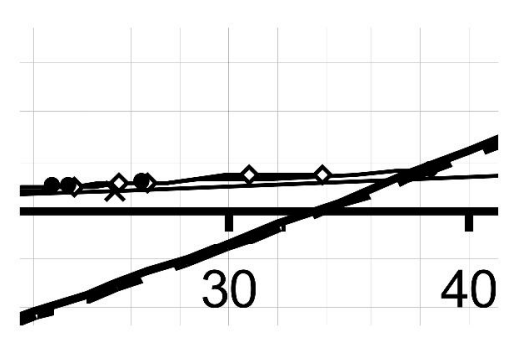

Slika 11. Ponašanje funkcije $N$-M sa porastom opterećenja prema linearnoj (LIN) $i$ geometrijski nelinearnoj analizi - predvidanje Green-Lagrange-a (LAG) $i$ von Karman-a

(VK): a) u ivičnoj gredi $i$ b) u čvornoj liniji 1, na sredini raspona poliedarskih ljuski raspona $L=20 m$ (levo) $i L=30 m$ (desno)

U slučaju dugih poliedarskih ljuski LIN analiza takođe gotovo uvek daje rezultate na strani sigurnosti. Izuzetak je presek ivične grede na sredini raspona, gde su prema VK predviđanjima dobijeni koeficijenti sigurnosti $\gamma(N)$ za 4.6\% (za krivu "A") odnosno 4.4\% (za krivu "B") niži nego koeficijenti sigurnosti sračunati prema LIN predviđanju, dok se odgovarajući koeficijenti sigurnosti $\gamma(q)$ međusobno razlikuju za $2.4 \%$, odnosno $2.2 \%$. Međutim, razlika između koeficijenata sigurnosti određenih na osnovu linearne $\mathbf{i}$ geometrijski nelinearne analize je u slučaju poliedarske ljuske raspona $L=30 \mathrm{~m}$ znatno veća nego kod ljuske srednjeg raspona, naročito u preseku u temenu ljuske (čvorna linija 1). Prema VK predviđanju, koeficijent $\gamma(N)$ je $30 \%$ veći nego prema LIN analizi, dok je odgovarajući $\gamma(q)$ veći za $25.91 \%$. 
Tabela 1. Granična nosivost i globalni koeficijenti sigurnosti ivične grede u sredini raspona poliedarskih liuski

\begin{tabular}{|c|c|c|c|c|c|}
\hline \multirow{2}{*}{\multicolumn{2}{|c|}{$\begin{array}{c}\text { Raspon ljuske } \\
\text { Kombinacija radnih } \\
\text { dijagrama betona i čelika }\end{array}$}} & \multicolumn{2}{|c|}{$\mathrm{L}=20 \mathrm{~m}$} & \multicolumn{2}{|c|}{$\mathrm{L}=30 \mathrm{~m}$} \\
\hline & & A & B & A & B \\
\hline \multirow{4}{*}{$\begin{array}{l}\text { linearna } \\
\text { teorija } \\
(\text { LIN) }\end{array}$} & $\begin{array}{c}\text { eksploatacioni } \\
\text { uticaji }\end{array}$ & \multicolumn{2}{|c|}{$\begin{aligned} \mathrm{N} & =-777.75 \mathrm{kN} \\
\mathrm{M} & =149.62 \mathrm{kNm}\end{aligned}$} & \multicolumn{2}{|c|}{$\begin{array}{c}\mathrm{N}=-1556.753 \mathrm{kN} \\
\mathrm{M}=230.19 \mathrm{kNm}\end{array}$} \\
\hline & $\mathrm{N}_{\mathrm{u}}$ & -1490 & -1520 & -2830 & -2870 \\
\hline & $\gamma(\mathrm{N})$ & 1.916 & 1.954 & 1.818 & 1.843 \\
\hline & $\gamma(\mathrm{q})$ & 1.916 & 1.954 & 1.818 & 1.843 \\
\hline \multirow{4}{*}{$\begin{array}{l}\text { Green- } \\
\text { Lagrange } \\
\text { (LAG) }\end{array}$} & $\begin{array}{c}\text { eksploatacioni } \\
\text { uticaji }\end{array}$ & \multicolumn{2}{|c|}{$\begin{array}{l}\mathrm{N}=-763.477 \mathrm{kN} \\
\mathrm{M}=143.912 \mathrm{kNm}\end{array}$} & \multicolumn{2}{|c|}{$\begin{array}{c}\mathrm{N}=-1401.483 \mathrm{kN} \\
\mathrm{M}=176.17 \mathrm{kNm}\end{array}$} \\
\hline & $\mathrm{N}_{\mathrm{u}}$ & -1505 & -1550 & -2540 & -2560 \\
\hline & $\gamma(\mathrm{N})$ & 1.971 & 2.03 & 1.812 & 1.827 \\
\hline & $\gamma(q)$ & 2.008 & 2.07 & 1.905 & 1.922 \\
\hline \multirow{4}{*}{$\begin{array}{l}\text { von } \\
\text { Karman } \\
\text { (VK) }\end{array}$} & $\begin{array}{c}\text { eksploatacioni } \\
\text { uticaji }\end{array}$ & \multicolumn{2}{|c|}{$\begin{array}{l}\mathrm{N}=-776.517 \mathrm{kN} \\
\mathrm{M}=148.951 \mathrm{kNm}\end{array}$} & \multicolumn{2}{|c|}{$\begin{array}{c}\mathrm{N}=-1533.584 \mathrm{kN} \\
\mathrm{M}=213.33 \mathrm{kNm}\end{array}$} \\
\hline & $\mathrm{N}_{\mathrm{u}}$ & -1490 & -1520 & -2660 & -2700 \\
\hline & $\gamma(\mathrm{N})$ & 1.919 & 1.957 & 1.734 & 1.761 \\
\hline & $\gamma(q)$ & 1.926 & 1.965 & 1.7745 & 1.8025 \\
\hline
\end{tabular}

Tabela 2. Granična nosivost i globalni koeficijenti sigurnosti poprečnog preseka u čvornoj liniji 1 u sredini raspona poliedarskih ljuski

\begin{tabular}{|c|c|c|c|c|c|}
\hline \multirow{2}{*}{\multicolumn{2}{|c|}{$\begin{array}{c}\text { Raspon ljuske } \\
\text { Kombinacija radnih } \\
\text { dijagrama betona i čelika } \\
\end{array}$}} & \multicolumn{2}{|c|}{$\mathrm{L}=20 \mathrm{~m}$} & \multicolumn{2}{|c|}{$\mathrm{L}=30 \mathrm{~m}$} \\
\hline & & A & B & A & B \\
\hline \multirow{4}{*}{$\begin{array}{l}\text { linearna } \\
\text { teorija } \\
\text { (LIN) }\end{array}$} & $\begin{array}{c}\text { eksploatacioni } \\
\text { uticaji }\end{array}$ & \multicolumn{2}{|c|}{$\begin{array}{l}\mathrm{N}=44.568 \mathrm{kN} \\
\mathrm{M}=8.35 \mathrm{kNm}\end{array}$} & \multicolumn{2}{|c|}{$\begin{aligned} \mathrm{N} & =51.647 \mathrm{kN} ; \\
\mathrm{M} & =15.339 \mathrm{kNm}\end{aligned}$} \\
\hline & $\mathrm{N}_{\mathrm{u}}$ & 99 & 105 & 120 & 128 \\
\hline & $\gamma(\mathrm{N})$ & 2.221 & 2.356 & 2.323 & 2.478 \\
\hline & $\gamma(q)$ & 2.221 & 2.356 & 2.323 & 2.478 \\
\hline \multirow{4}{*}{$\begin{array}{c}\text { Green- } \\
\text { Lagrange } \\
\text { (LAG) }\end{array}$} & $\begin{array}{c}\text { eksploatacioni } \\
\text { uticaji }\end{array}$ & \multicolumn{2}{|c|}{$\begin{array}{l}\mathrm{N}=44.325 \mathrm{kN} \\
\mathrm{M}=8.22 \mathrm{kNm}\end{array}$} & \multicolumn{2}{|c|}{$\begin{array}{l}\mathrm{N}=50.741 \mathrm{kN} ; \\
\mathrm{M}=13.32 \mathrm{kNm}\end{array}$} \\
\hline & $\mathrm{N}_{\mathrm{u}}$ & 100 & 105 & $\begin{array}{c}\text { nije } \\
\text { dostignuta }\end{array}$ & $\begin{array}{c}\text { nije } \\
\text { dostignuta }\end{array}$ \\
\hline & $\gamma(\mathrm{N})$ & 2.256 & 2.369 & - & - \\
\hline & $\gamma(q)$ & 2.260 & 2.373 & - & - \\
\hline \multirow{4}{*}{$\begin{array}{c}\text { von } \\
\text { Karman } \\
\text { (VK) }\end{array}$} & $\begin{array}{c}\text { eksploatacioni } \\
\text { uticaji }\end{array}$ & \multicolumn{2}{|c|}{$\begin{array}{l}\mathrm{N}=44.335 \mathrm{kN} \\
\mathrm{M}-8.30 \mathrm{kNm}\end{array}$} & \multicolumn{2}{|c|}{$\begin{array}{l}\mathrm{N}=52.309 \mathrm{kN} \\
\mathrm{M}-14.70 \mathrm{kNm}\end{array}$} \\
\hline & $\mathrm{N}_{\mathrm{u}}$ & 100 & 105 & 158 & 170 \\
\hline & $\gamma(\mathrm{N})$ & 2.256 & 2.368 & 3.02 & 3.25 \\
\hline & $\gamma(q)$ & 2.254 & 2.365 & 2.925 & 3.143 \\
\hline
\end{tabular}




\section{ZAKLJUČAK}

Pogodan metod za analizu armiranobetonskih prizmatičnih poliedarskih ljuski je metod konačnih traka (MKT). Ovaj metod može biti zasnovan na pretpostavci o linearnom ponašanju konstrukcije (LIN), što je u većini slučajeva opravdano pri analizi poliedarskih ljuski malog raspona.

Geometrijski nelinearno ponašanje konstrukcije ne sme se zanemariti kod analize dugih poliedarskih ljuski, kod kojih se preporučuje primena harmonijski spojenog metoda konačnih traka (HSMKT), zasnovanog na pretpostavkama Green-Lagrange-a (LAG) ili von Karman-a (VK). HSMKT je složeniji i zahtevniji u pogledu kapaciteta računara i utroška vremena, pa je razumljiva težnja da se upotreba klasičnog MKT postupka proširi i na poliedarske ljuske srednje dužine, pod uslovom da to ne umanji ni njihovu pouzdanost niti ekonomičnost.

Uporednom analizom dve armiranobetonske prizmatične poliedarske ljuske raspona $20 \mathrm{~m}$ (ljuska srednje dužine) i $30 \mathrm{~m}$ (duga ljuska), kroz određivanje presečnih uticaja primenom LIN, LAG i VK postupka, preko dimenzionisanja prema LIN uticajima i konstruisanja dijagrama interakcije karakterističnih preseka, do određivanja njihove granične nosivosti, graničnog opterećenja i globalnih koeficijenata sigurnosti, došlo se do zaključka o racionalnom metodu proračuna ovih konstrukcija u funkciji njihovog raspona. Pokazalo se da LIN analiza armiranobetonske poliedarske ljuske srednje dužine daje presečne uticaje i dimenzije konstrukcije koji se nalaze na strani sigurnosti u odnosu na rezultate geometrijski nelinearne analize, te da do loma karakterističnih preseka prema LAG i VK predviđanjima dolazi pri višem nivou opterećenja nego što se dobija linearnom analizom. Najveća uočena odstupanja u rezultatima LIN i geometrijski nelinearne analize ne prelaze $6 \%$.

Zbog svega navedenog može se zaključiti da je linearan metod konačnih traka optimalan metod za proračun armiranobetonskih poliedarskih ljuski srednje dužine. U slučaju dugih ljuski, razlika između rezultata linearne i geometrijski nelinearne analize je izraženija, pri čemu LIN analiza ne daje uvek rezultate na strani sigurnosti.

Ovim je potvrđen raniji stav da se za proračun dugih armiranobetonskih poliedarskih ljuski mora primeniti metod zasnovan na pretpostavci velikih pomeranja. Jedan od proverenih raspoloživih metoda je i HSMKT.

\section{LITERATURA}

[1] Milašinović, D. D.: Metod konačnih traka u teoriji konstrukcija, Student, Novi Sad, 1994.

[2] Milašinović, D. D.: Geometric non-linear analysis of thin plate structures using the harmonic coupled finite strip method, Thin-Walled Structures, 49(2), 280-290, 2011.

[3] Milašinović, D.D., Goleš, D., Hajduković, M., Nikolić, M., Marić, P., Živanov, Ž., Rakić, P. S.: Harmonic Coupled Finite Strip Method Applied on Geometric Nonlinear Analysis of Reinforced Concrete Folded Plate Structures, The Fourteenth International Conference on Civil, Structural and Environmental Engineering Computing, Cagliari, Sardinia, Italy, 3-6 September 2013.

[4] Hajduković, M., Milašinović, D.D., Goleš, D., Nikolić, M., Marić, P., Živanov, Z. and Rakić, P.S.: Cloud Computing based MPI/OpenMP Parallelization of the 
Harmonic Coupled Finite Strip Method applied to Large Displacement Stability Analysis of Prismatic Shell Structures, in B.H.V. Topping, P. Iványi, (Editors) "Proceedings of the Third International Conference on Parallel, Distributed, Grid and Cloud Computing for Engineering", Civil-Comp Press, Stirlingshire, United Kingdom, paper 47, 2013. doi:10.4203/ccp.101.47.

[5] Goleš, D., Milašinović, D.: Analiza uticaja "dubine" poliedarske ljuske na presečne sile i pomcranja, Zbornik radova GF Subotica, 2012, str. 41-49.

[6] Goleš, D., Milašinović, D.: Analiza uticaja dužine poliedarske ljuske na presečne sile i pomeranja, Zbornik radova GF Subotica, 2012, str. 19-27.

[7] Goleš, D.: Reološko-dinamička analiza armiranobetonskih poliedarskih ljuski, Doktorska disertacija, Građevinski fakultet Subotica, jun 2012.

[8] Milašinović, D., Goleš, D.: Analiza stabilnosti armiranobetonskih složenica, Građevinar 65, br. 5, 2013, str. 411-422.

[9] Milašinović, D. D., Goleš, D., Borković, A., Kukaras, D., Landović, A., Živanov, Z., Rakić, P.: Rheological-Dynamical Limit Analysis of Reinforced Concrete Folded Plate Structures using the Harmonic Coupled Finite-Strip Method, in B.H.V. Topping, (Editor), "Proceedings of the Eleventh International Conference on Computational Structures Technology", Civil-Comp Press, Stirlingshire, UK, Paper 158, 2012. doi: $10.4203 / \mathrm{ccp} .99 .158$.

[10] Milašinović, D.D., Goleš, D.: Finite strip modeling for optimal design of reinforced concrete folded plate structures, Facta Universitatis, Series: Architecture and Civil Engineering, Vol. 10, $\mathrm{N}^{\mathrm{o}} 3$, 2012, pp. 275-290.

\title{
SELECTION OF RATIONAL METHOD OF ANALYSIS FOR REINFORCED CONCRETE FOLDED PLATE STRUCTURES REGARDING TO THEIR SPAN LENGTH
}

\begin{abstract}
Summary: Two reinforced concrete folded plate structures of span length 20 and $30 \mathrm{~m}$ are designed according to internal forces calculated using linear finite strip method. Diagrams of interaction with curves of fracture are drawn for selected characteristic cross-sections, using working diagrams of concrete and reinforcement according to Eurocode 2 and rheological-dynamical analogy. The ultimate load, at which the fracture of characteristic cross-sections occurs, is determined by successive increase of load through the geometric nonlinear analysis of structures using harmonic coupled finite strip method. Comparing the safety factors calculated from the results of linear and geometric nonlinear analysis, the conclusion about the rational method of analysis, regarding to the length of structure, is made.
\end{abstract}

Keywords: Reinforced concrete, folded plate, finite strip method, linear analysis, geometric nonlinear analysis, span length 